\title{
TRANSLATION: COVID-19, NEW TECHNOLOGIES, PRODUCTIVITY AND BUSINESS' EMERGENCY PLAN*
}

\author{
Milagros Morales** \\ https://orcid.org/0000-0002-2584-2330
}

RECIBIDO: Mayo 2021 / ACEPTADO: Junio 2021 / PUBLICADO: Septiembre 2021

Como citar: Morales, Milagros. (2021). Traducción: Covid-19, new technologies, productivity and business' emergency plan. Telos: revista de Estudios Interdisciplinarios en Ciencias Sociales, 23 (3), Venezuela. (Pp. 764-773).

DOI: www.doi.org/10.36390/telos233.16

\begin{abstract}
The Covid -19 outbreak caused great uncertainty in whole companies' sectors and levels. In general, companies have been forced to make changes and adjustments to adapt to new needs. This research aims to provide managers and business directors some tools to reduce risks in decision-making and minimize economic and health losses in employees. By implementing emergency plans, risk management, creating trust, and effective communication between the different organization levels and areas. The research is inserted in the critical theory paradigm, an epistemological approach, a qualitative methodological perspective, and an evaluation and action research method. The theoretical foundation is based on the thinking of Armand V. Feigenbaum as a precursor of Total Quality Management (TQM) and project management to mitigate risks and emergencies. Finally, a set of reflections, evaluations, and proposals are showed as a conclusion to facilitate decision-making and companies' adaptability in crisis environments.
\end{abstract}

Keywords: COVID-19, productivity, risk management, project management, Total Quality Management.

Traducción: Covid-19, nuevas tecnologias, productividad y plan de emergencia empresarial

\section{RESUMEN}

El brote de Covid-19 causó gran incertidumbre en empresas de todos los sectores y niveles. En general, las empresas se han visto obligadas a realizar cambios y ajustes para adaptarse a la

\footnotetext{
* TEXTO ORIGINAL: Morales, Milagros. (2020). Covid-19, nuevas tecnologías, productividad y plan de emergencia empresarial. En Tendencias en la Investigación Universitaria. Una Visión desde Latinoamérica Volumen XI. (Pp. 21-36). Alianza de Investigadores Internacionales S.A.S. (ALININ). Colombia. https://doi.org/10.47212/tendencias2020vol.xi.3
}

** Master's degree in Business Administration, Atlantis University, Miami, Florida, United States. Email: Info.milagrosmorales@gmail.com; www.milagrosmorales.com 
demanda de nuevas necesidades. El objetivo de esta investigación es brindar herramientas a gerentes y directivos empresariales con el fin de reducir riesgos en la toma de decisiones, minimizar pérdidas económicas y de salud en los empleados, por medio de la implementación de planes de emergencia, manejo de riesgos, fomento de la confianza y comunicación efectiva entre los distintos niveles y áreas de la organización. La investigación se inserta en el paradigma de teoría crítica, un enfoque epistemológico, perspectiva metodológica cualitativa y método de investigación, evaluación y acción. La fundamentación teórica está basada en el pensamiento de Armand V. Feigenbaum como precursor del Total Quality Management y la implementación de proyectos para mitigar riesgos y emergencias. Finalmente se presenta, a manera de conclusión, un conjunto de reflexiones, evaluaciones y propuestas diseñadas para facilitar la toma de decisiones y la adaptabilidad de las empresas a entornos de crisis.

Palabras claves: COVID-19, productividad, manejo de riesgos, gerencia de proyectos, gestión de calidad total.

\section{Introduction}

COVID-19 brought significant challenges for the business community. Various sectors adapted their infrastructure and management design. Most of the companies manifested a growing resilience that allowed them to strengthen themselves for the future, generate new ideas, and meet the needs of their employees, customers, and suppliers. The main disadvantages that small and medium-sized companies face are difficulties in cash flow, losses of working capital, poor distribution, and customer service.

These needs inside and outside the company must be met through a rapid transition to digital. This research aims to provide tools and solutions to the managers and directors of companies based on quality management and project management to minimize risk in decisionmaking, reduce losses, meet new consumption patterns of the population, and create a safe work environment. According to Stevenson (2002), quality management or Total Quality Management is a method or philosophy that involves everyone in the organization in a continuous effort to improve quality and overcome the balance of customer satisfaction in the short and long term, increase engaging employees, and to achieve consistent goals.

The inputs and outputs give the variables. Outputs as goods and services; and inputs such as raw materials, inventory, technologies, and human capital. We will study the implementation of measures and procedures in emergency management through project management to increase productivity. Although it has great similarities, this chapter does not cover other quality management topics such as Six-sigma. It focuses more on improving production, not the collaboration between people and organizations such as Total Quality Management (TQM).

\section{Theoretical foundation}

The root of the word quality comes from the Latin qualitatem (qualitas), which establishes quality as a property, nature, state, or condition. According to Jens (2007), quality meets the client's requirements, aligning the characteristics of the product or service that the client expects to receive.

The American Society for Quality (2020) considers Walter A. Shewhart the first exponent of quality management; his contribution was developing statistical analysis and quality control in 
Traducción: Covid-19, new technologies, productivity and business' emergency plan.

1930. Between 1950 and 1967, Successive exponents such as W. Edwards Deming, considered the founder of Total Quality Management (TQM), and Armand V. Feigenbaum, among others, made great contributions to increasing many companies' quality. Currently, Total Quality Management is considered an international standard in the development of organizations. The principles and processes of Total Quality Management are used in the ISO 9000 series of quality control standards.

Hashmi (2020) states that Total Quality Management is a method by which management and employees can get involved in the continuous improvement of the production of goods and services. It is a combination of management and quality tools designed to increase productivity and reduce losses. The principle of this method describes the organizational culture and the effort to satisfy consumer needs by providing quality products and services.

Considering that variables are outputs of goods and services, materials, resources, technology, and human capital are inputs. It is essential to refer to the term productivity and its respective equation. That allows obtaining a higher level of profitability through the standardization and optimization of processes, using strategies that allow increased efficiency and differentiating from competitors.

Therefore, it can say that productivity is the measure of effective use of resources expressed in terms of costs and efficiency (Echavarría, 2019). History shows that companies and countries, and individuals obtain prosperity by creating and transforming ideas into products and services, tangible and intangible, through strategies and production systems that make profits and reduce costs. (Pride, 2014).

Currently, productivity is an important factor that managers, executives, and investments obtain from human capital, materials, monetary liquidity, assets, infrastructure, energy, advertising, social responsibility, copyrights, patents, among others. The formula to measure productivity is given by the quotient between the supplied product and the resources.

$$
\text { productivity }=\frac{\text { outputs }}{\text { inputs }} ;=\frac{(\text { goods, } \text {, } \text { ervices })}{(\text { material }, \text { labor }, \text { energy })}
$$

According to Reinboth (2014), productivity is reduced mainly by expenses, waste, and inefficiencies, which can accentuate the economic imbalance of the organization. Today, more than ever, in the context of COVID-19, countries, companies, and individuals seek to increase productivity in different areas of life: social, economic, physical, and spiritual health. Therefore, strategies and models that promote adaptation to new social and business environments are studied, evaluated, designed, developed, and implemented. Determined by implementing social distancing measures, consumer behavior changes, and the digitization and purchasing patterns focused on essential areas such as food, hygiene, and cleaning.

\section{Methodology}

Total Quality Management has an important impact on different company areas, such as planning, administration, quality control, customer service, market performance, employee selection, training, and motivation. The research focuses on small and medium-sized companies evaluating the impact of quality management, implementing emergency plans to mitigate the effects of COVID-19, and increasing productivity, using online tools that allow a transition to the 
digital world. In this way, it guarantees the survival of companies, safety in the work environment, and meets the demands of consumers.

This research mainly uses statistics taken in specialized databases such as The United States Census Bureau and Statista. The analyzed digital data is based on surveys of retail companies affected by the Pandemic, companies that sought tax relief, and resorted to implementing new tools to meet consumer demand. Additionally, data was analyzed on the increase in online purchases, the increase in income from sales of products on digital platforms, and the transfer of consumption patterns to online commerce, in people of all ages. The data were analyzed with business intelligence tools.

\section{Method}

The research is inserted in the paradigm of critical theory and epistemological approach to observe the facts in the present society marked by the effects of COVID-19. This historical moment allows us to analyze, evaluate and learn from the mistakes and successes committed as a society. A qualitative methodological perspective and research, evaluation, and action method. With the qualitative perspective, as with the research, evaluation, and action method, an interpretive-evaluative approach is achieved that allows diagnosing, describing, planning, and implementing proposals for decision-making and mitigating the effects caused by the Pandemic on small businesses. And medium-sized companies.

\section{Results and Discussion}

According to The United States Census Bureau (2020), a significant percentage of companies were affected by COVID-19 in the first four months of this year. Around $51.4 \%$ present difficulties in operations, and their expectations of returning and normal operation levels extend until 2021. The most affected sector was restaurants, tourist services, entertainment, and traditional retail stores with a physical presence in the community.

On the contrary, consumer preferences were transferred to the online shopping sector with an evident increase in the first six months of the year on average greater than $30 \%$. According to Statista (2020), the sectors that benefited from the consumption preference were hygiene and health, with a percentage greater than $43 \%$. That includes purchase products such as medicines and antibacterials. They were following for the food and beverage sector with a ratio greater than $40 \%$. The online entertainment sector benefited from subscriptions to digital platforms for movies, games, videos, books, and education.

In this sense, companies make efforts to develop ways that will allow them to stay in the market, solve challenges on the way to digitization and comply with the distribution of their products and services. Technology can considerably improve productivity in companies and reduce costs in the areas that the emergency plan allows. The fundamental objective of these processes is people; the focus on an emergency plan is human.

To strengthen the company is to strengthen its workers and its consumers. Obtaining the benefits of improvements in service quality and work environment "based on the human essence and in spaces of an action directed to the search. Of the quality of life of the social actors of the organization" (Barbera, 2019, pp. 211-224).

There are important factors that need to be successful when implementing an emergency plan. That requires a good manager, design, careful planning, proper risk management, and solid 
Traducción: Covid-19, new technologies, productivity and business' emergency plan.

project closure. According to Verzuh (2003), organizations can create successful projects by implementing conceptual development, planning, administration, and control of resources.

A proposal is presented due to the theoretical review and statistical analysis on the effects caused by COVID-19 in small and medium-sized companies. An action plan is developed to face various variables to be executed, such as difficulties with suppliers, telework, online sales, and a marketing plan, expressed below.

\section{Proposal.}

\section{Section one. Define a schedule, objectives, and scope of the plan:}

This session is important to know how affected the company is and the estimated survival time to establish an adjusted resolution and afloat time according to the available resources. Also, evaluate how COVID-19 impacted the sector and the market the company is targeting. This information is available on official governments' websites and world organizations such as the United Nations (UN) and the World Health Organization.

These organizations also provide information on obtaining resources, loans, and education to overcome the crisis. An example of this is The Small Business Administration (SBA) which published a "Small Business Resource Guide" (SBA, 2020, pp. 1-52). The SBA also offers guides for dealing with different natural disasters and guides for obtaining loans available on its platform: "The Federal Emergency Management Agency (FEMA) checklist and series of emergency preparedness resources. In English)" (SBA, 2020).

The United Nations International Children's Emergency Fund (UNICEF) published "Key messages and actions for COVID-19, prevention and control in schools" (UNICEF, 2020, pp. 113, as cited in Morales, 2020). Based on past epidemics, the Centers for Disease Control and Prevention published "Community Mitigation Guidelines for Preventing Pandemic Influenza" (CDC, 2017, pp. 1-34). Similarly, the World Health Organization presented information on fiscal measures and incentives offered by different countries (Chen, 2020). In addition, the International Labor Organization (OTI) (as cited in 2020) highlighted the risks associated with the Pandemic and its impact on the labor market, working together with governments to provide comprehensive solutions to companies and their workers.

The success of this session lies in defining the plan and the affected variables or objectives to be achieved, if possible, to execute them consecutively and focus efforts on the priority areas. The critical point is to determine what facts can affect the development of the plan and the achievement of the objectives. Such as the illness of employees or family members due to Pandemic, difficulty obtaining resources, and state and national regulations implementation. Also, the deficit in digital knowledge, challenges in implementation and adjustments to the technological area, difficulties in obtaining inventory, and difficulties in distributing products or services.

\section{Section two. Create the action plan:}

In this part of the plan, it is essential to define who will participate, their skills, and where the efforts in resources and human capital are directed. Similarly, assess capabilities and build teams, assign responsible for departments and tasks. It is also essential to divide the work into small activities, distribute them to each team member, and set deadlines. 
Cost estimating and resource management allows you to increase productivity by choosing only essential areas to implement improvements. A company must know how much resources, time, and effort it requires to reach the goal before implementing improvements or emergency plans. It is having the availability of costs to allocate resources and perform tasks.

The main tasks and areas in an emergency plan due to COVID-19 are usually focused on obtaining financial resources, training staff in teleworking, and meeting the emerging needs of clients.

Financial resources: The main support for obtaining financial resources will be the banking partners and the company's accountant. Each country has government entities, associations, chambers of commerce, affiliated banks, and non-profit organizations specialized in financing specific economic sectors. The sectors affected by the Pandemic are tourism and hotels, airlines and cruises, entertainment such as cinemas, and music and sporting events companies. They saw their annual income declining almost entirely, which is why they turned to federal loans to maintain payroll and cover basic costs.

Teleworking: Teleworking has been on the rise in recent years. However, by 2020, teleworking had an exponential increase when many companies sent their workers to perform mainly administrative tasks from home. That brings benefits for the company in reducing the cost of energy, services, and space. For employees, the benefit is shown in terms of travel time and comfort when working from home. An increase in employees' effectiveness and, therefore, of the company has been shown; for them, many platforms make their services available, minimizing communication problems. Examples of this are social networks, teleconferencing tools, sales management and lead creation, online accounting administrative programs, continuing education, and online updating.

Technology use and online marketing: Technology helps provide a better service and companies to the customer by interacting directly with the consumer through networks. That allows us to better understand the client and their needs, offer personalized services, and satisfy the demanding delivery times of today's consumers. Companies must use and manage the cloud, to calculate and save the data generated in all areas, payroll, accounting, customer service.

\section{Section three. Risk management:}

These processes must be carried out continuously throughout the life cycle of the project or emergency plan. Risk management makes it possible to identify and reduce existing threats (Brantley, 2007). At this point, the strengths and weaknesses of the organization must be revealed in the search for effectiveness; the company must hire third parties if it does not have the internal capacities and technological competencies. You should also develop a list of substitute providers in case of failures with traditional providers.

\section{Section Four. Evaluation, project control, and closure:}

The control function for company managers includes monitoring the progress and timing of tasks and resources. Pinto (2019) suggests communicating with the work team and stakeholders, monitoring quality in decision-making to ensure adequate participation and productivity, maintaining the cost-schedule-quality balance, and taking corrective measures to keep the project on track. March. Monitoring and controlling is a key factor in ensuring the completion of the plan on time and with adequate resources (Business Insight Ltd, 2020). 
Traducción: Covid-19, new technologies, productivity and business' emergency plan.

The completion of an emergency plan goes beyond the delivery of the product or the achievement of the objectives. It must guarantee customer satisfaction and an adequate work environment. Remembering that the focus of total quality management is improvement and integration between people and the organization. An important goal of project closure is to capture the lessons learned to be passed on to the organization.

For this reason, two graphs resulting from the analysis of data obtained on companies affected by COVID-19, which implemented adaptations on the way to digitization, are included below. In the curves of the first table, we can observe a marked closure of companies at the beginning of Pandemic and a gradual reopening with the passing of the months. What in practice meant reducing consumers and, therefore, a drastic decrease in sales and income. On the contrary, buying pattern of consumers was transferred to digital platforms where an average increase in sales and income of $30 \%$ is observed, which is maintained despite the reopening of retail stores. Table two shows the main changes implemented by companies to comply with regulations and increase sales with a view to the final reopening.

Tables, Charts, and Graphs:

\section{Closing and Reopening}

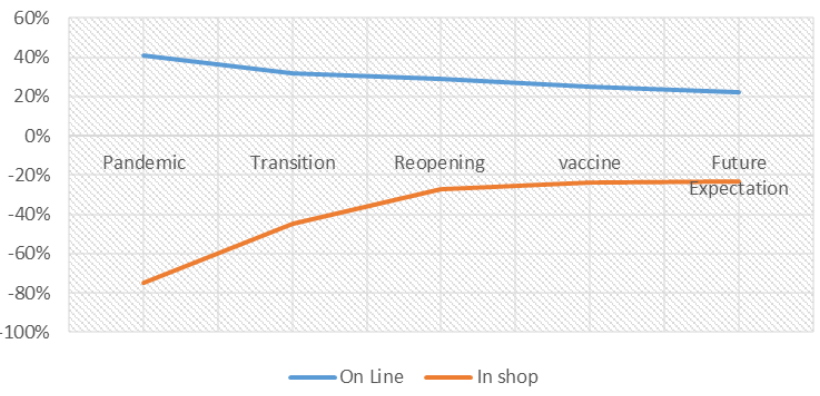

Source: Graphic prepared by the author.

Implemented Changes

= Average number of companies
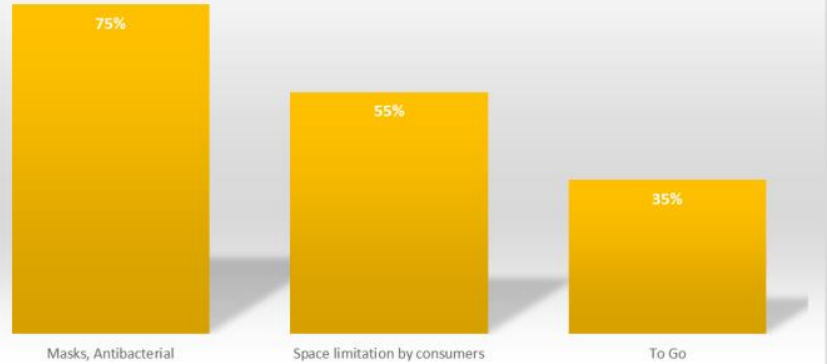

Source: Graphic prepared by the author. 


\section{Graphics Discussion}

About $50 \%$ of retail companies reopened their doors, around $30 \%$ remained open during the Pandemic, and a percentage close to $10 \%$ closed permanently. Most of these companies made changes to comply with regulations and safeguard the health of their workers and customers. The most visible changes were the mandatory use of masks for employees and consumers, establishing limits of consumers who enter the establishment, and implementing online sales and payment or carrying out.

\section{Conclusions}

Companies are wealth generators and seek to achieve greater productivity by creating and distributing goods and services. Organizations of all levels and sectors are currently affected by COVID'19, economic losses, human capital losses, and the change in consumption patterns prompted the implementation of emergency plans. New hygiene and social distancing measures marked the beginning to develop strategies and adapt quickly to digitization, teleworking tools, video conferencing, and digitization in sales and payment methods.

The proper use of technological tools combined with total quality management strategies helps increase productivity in companies, reduce costs, and maintain a connection with customers, suppliers, and employees. It also allows to evaluate the company's financial health better and use techniques such as inventory control, value analysis, and data analysis to take care of resources.

As we have seen, many factors influence the increase or decrease in productivity and resilience of a company to adapt to new requirements and demands. Retail companies have seen their revenues reduced almost entirely. However, online sales platforms increased their sales by around $30 \%$. And, in the first year half, the business community has resisted attacks and difficulties caused by the Pandemic, in a number greater than $50 \%$.

The use of total quality management in an organization favors planning, risk management and facilitates proper decision-making. Productivity can be positive and negative using resources, capital investments, equipment, modification, human capital, technological changes, work methods, and systems.

For this reason, it is essential to establish reasonable goals for the improvement of operations inside and outside the company, to prepare and implement an emergency plan that includes quality management and productivity. Decide what area is essential, the critical point, review strengths and weaknesses, determine the available resources, and finally capture the lessons learned and transmit them to strengthen the organization's future and achieve the longawaited differentiation over competitors.

\section{Bibliographic References ${ }^{1}$}

ASC. (2020). History of Total Quality Control Management. Retrieved from https://asq.org/quality-resources/total-quality-management/tqm-history

Barbera, N. (2019). Bioética gerencial. Nueva forma de dirigir las organizaciones universitarias. Tendencias en la Investigación Universitaria. Una visión desde Latinoamérica., 7 (7), 211 -

${ }^{1}$ References are as they were in the original document; it does not follow journal normative. 
Traducción: Covid-19, new technologies, productivity and business' emergency plan.

224. Coro. Venezuela. Fondo Editorial Servando Garcés. www.doi.org/10.47212/Tendencias_vii_2019_15

BInsight. (2020). "The Critical Path" Retrieved from https://2020projectmanagement.com/resources/project-planning/what-is-the-critical-path Brantley, W. (2007). "The Five Secrets to Project Success" Villanova University. Retrieved from www.VillanovaU.com and http://docplayer.net/6634688-The-five-secrets-to-projectsuccess.html

CDC. (2017). "Community Mitigation Guidelines to Prevent Pandemic Influenza", Morbidity and Mortality Weekly Report, 66(1)1-34, Retrieved from https://www.cdc.gov/mmwr/volumes/66/rr/rr6601a1.htm

Chen, H. (2020). The Impact of the COVID-19 Pandemic on Consumption: Learning from High Frequency Transaction Data. By http://dx.doi.org/10.2139/ssrn.3568574

Echavarría, J. (2019). "Protección y productividad en la industria colombiana, 1993-2011," Borradores de Economía 1082, Banco de la Republica de Colombia. DOl: 10.32468/be.1082

Hashmi, K. (2020). "Introduction and implementation of total quality management (TQM)" Retrieved from https://www.isixsigma.com/methodology/total-quality-managementtgm/introduction-and-implementation-total-quality-management-tam/

Jens, D. (2007). Fundamentals of Total Quality Management" Taylor and Francis, edition elibrary (p.11) New York. Retrieved from edition e- library. EBookstore.tandf.co.uk https://books.google.com/books?hl=en\&lr=\&id=kuSQAgAAQBAJ\&oi=fnd\&pg=PP1\&dq=tot al+quality+control+management\&ots=dLNdsfHdE3\&sig=LpyPw1bhvX-

qIU7kHPILpnOenXc\#v=onepage\&q=total\%20quality\%20control\%20management\&f=false

Maldonado, M. (2020). Formación por competencias en el contexto provocado por la pandemia del COVID-19. Tendencias en la Investigación Universitaria. Una visión desde Latinoamérica., v. IX Colección Global, Coro. Venezuela. Fondo Editorial Servando Garcés v. www.doi.org/10.47212/tendencias2020vol.ix.15

Morales, M. (2020). "Applied mathematics in crisis scenarios (covid-19)". EDUCARE - UPEL-IPB - V 2.0, 24(2), 353-366. Retrieved from https://doi.org/10.46498/reduipb.v24i2.1335

OIT. (2020). El COVID-19 y el mundo del trabajo. Ed. 4. Recuperado de https://reliefweb.int/sites/reliefweb.int/files/resources/Observatorio $\% 20 \mathrm{de} \% 201 \mathrm{a} \% 20 \mathrm{OIT} \% 2$ 0\%20El\%20COVID\%E2\%80\%9119\%20y\%20el\%20mundo\%20del\%20trabajo.\%20Cuarta \%20edici\%C3\%B3n.pdf

Pinto, J. (2019). Project Management, Achieving Competitive Advantage. Fifth Edition, Pearson Education, Inc. New York, NY. United State.

Pride. W (2014). "Business". (p. 216). Mason, South-Western Cengage Learning, OH, United State.

Reinboth, C. (2014). "Operations Management Basics: What is productivity?" Posted by SAP community. Retrieved from https://blogs.sap.com/2014/09/22/operations-managementbasics-what-is-productivity/

SBA. (2020). La lista de control y serie de recursos de preparación en caso de emergencias de la Agencia Federal para el Manejo de Emergencias (FEMA, por sus siglas en inglés). Recuperado de https://www.sba.gov/guia-de-negocios/administre-su-empresa/preparesepara-emergencias 
SBA. (2020). Pequeñas Empresas Guía de Recursos. Recuperado de https://www.sba.gov/sites/default/files/files/resourceguide_national_spanish.pdf

Statista. (2020). Products and services people spend more than usual on due to the COVID-19 / coronavirus pandemic in the united Stated, United Kingdom and Germany 2020. Retrieved from https://www.statista.com/statistic/1108088/products-and-services-people-spendmore-on-due-to-the-covid-19-pandemicl

Stevenson, W. (2002). Operation Management - series Operation and Decision Sciences. 7th ed. (p. 51) McGraw Hill Irwin, Boston, United Stated.

UNICEF, (2020). "Key Messages and Actions for COVID-19 Prevention and Control in Schools" New York, Retrieved from https://www.who.int/docs/default-source/coronaviruse/keymessages-and-actions-for-covid-19-prevention-and-control-in-schools-march2020.pdf?sfvrsn=baf81d52_4

USCB. (2020). Weekly Census Bureau Survey Provides Near-Real-Time Info on Businesses. Retrieved from https://www.census.gov/library/stories/2020/05/new-small-business-pulsesurvey-shows-breadth-of-covid-19-impact-on-businesses.html

Verzu, E. (2003). Project Management. John Wiley \& Sons, Inc. New Jersey. United States. 